Nicholas, D. J. D. (1957). J. gen. Microbiol. 17, 689-698

\title{
The Effect of Molybdenum Deficiency on the Catalase and Peroxidase Content of Neurospora crassa
}

\author{
By D. J. D. NICHOLAS \\ A.R.C. Unit of Plant Nutrition (Micronutrients), Long Ashton \\ Research Station, University of Bristol
}

SUMMARY: Catalase and peroxidase were markedly decreased in quantity in molybdenum-deficient felts of Neurospora crassa. Addition of molybdenum aseptically and in vivo to mats deficient in molybdenum restored the activities of the two enzymes and the yield of mycelium to the amounts in the control treatments. Infiltration of hydrogen peroxide to growing felts, deficient in molybdenum, after 3 days of growth, resulted in a partial reconstitution of catalase to $18 \%$ and peroxidase to $50 \%$ of the control levels after a further 2 days growth but the weight of mycelium remained unchanged. There was no positive correlation between the activity of either enzyme at various stages of purification and its molybdenum content as determined by a radioassay method. The purified enzymes were not activated by molybdenum. The effect of molybdenum deficiency on the two ironcontaining enzymes is probably indirect, resulting from a decrease in the activity of molybdenum-dependent flavoproteins which produce hydrogen peroxide, the common substrate for catalase and peroxidase.

In recent years molybdenum has been shown to be essential for the metabolism of some micro-organisms, higher plants and animals. Molybdenum is a constituent of nitrate reductase found in some bacteria (Nicholas \& Nason, 1954c), in fungi (Nicholas, Nason \& McElroy, 1954; Nicholas \& Nason, 1954 $a, b)$, and in green plants (Nicholas \& Nason, 1955). During the enzymic reduction of nitrate, molybdenum undergoes a valency change involving $\mathrm{Mo}^{6+}$ and $\mathrm{Mo}^{5+}$ (Nicholas \& Stevens, 1955). When ammonium ion is the only source of nitrogen, however, nitrate reductase does not usually form in plants and the molybdenum requirement, although considerably decreased, is not completely eliminated. Thus molybdenum appears to be required for metabolic processes other than for the reduction of nitrate. The present paper amplifies a preliminary publication in which it was shown that a deficiency of molybdenum in Neurospora crassa, wild type 146, decreased the amounts of catalase and peroxidase obtained in cell-free extracts of the mycelial felts (Nicholas, 1956). It is also indicated that the decrease in amount of the two iron-containing enzymes is probably caused by a diminution of hydrogen peroxide production in Mo-deficient felts.

\section{METHODS}

Organism. Neurospora crassa, microconidial, wild type 146, was kindly supplied by Dr William D. McElroy (McCollum-Pratt Institute, Johns Hopkins University, Baltimore, U.S.A.). The fungus maintained at $30^{\circ}$ on nutrient agar slopes ( $20 \mathrm{~g}$. agar, $5 \mathrm{~g}$. yeast extract, $5 \mathrm{~g}$. malt extract/litre of 
culture medium) was subcultured weekly to ensure that it made vigorous growth.

Culture medium. The fungus was grown in the following basal liquid medium: sucrose, 20 g.; $\mathrm{NH}_{4} \mathrm{NO}_{3}, 2$ g.; $\mathrm{Na}$ tartrate, 1 g.; $\mathrm{KH}_{2} \mathrm{PO}_{4}, 3$ g.; $\mathrm{MgSO}_{4} .7 \mathrm{H}_{2} \mathrm{O}$, $0.5 \mathrm{~g}$; $\mathrm{NaCl}, 0 \cdot 1 \mathrm{~g}$; $\mathrm{CaCl}_{2}, 0 \cdot 1 \mathrm{~g}$; biotin, $5 \mu \mathrm{g}$.; $\mathrm{FeCl}_{3} .6 \mathrm{H}_{2} \mathrm{O}, 9 \cdot 6 \times 10^{-4} \mathrm{~g}$; $\mathrm{ZnSO}_{4} \cdot 7 \mathrm{H}_{2} \mathrm{O}, 8.8 \times 10^{-3}$ g.; $\mathrm{CuCl}_{2} \cdot 2 \mathrm{H}_{2} \mathrm{O}, 2.7 \times 10^{-4}$ g.; $\mathrm{MnCl}_{2} \cdot 4 \mathrm{H}_{2} \mathrm{O}, 7 \cdot 2 \times$ $10^{-5} \mathrm{~g}$; $\mathrm{Na}_{2} \mathrm{MoO}_{4} \cdot 2 \mathrm{H}_{2} \mathrm{O}, 1 \cdot 2 \times 10^{-5}$ g.; glass-distilled water to $1 \mathrm{l}$.; $\mathrm{pH} 4 \cdot 8$.

Removal of molybdenum from the basal medium. Molybdenum was effectively removed from a solution of the macronutrients including sucrose adjusted to pH 2.0 with $6 \mathrm{~N}-\mathrm{HCl}$, by the copper sulphide co-precipitation method (Nicholas \& Fielding, 1951; Nicholas, 1952). The $\mathrm{pH}$ was then re-adjusted to 4.8 with pure $\mathrm{NaOH}$, prepared by passing $5 \%(\mathrm{w} / \mathrm{v}) \mathrm{NaOH}$ through an Amberlite column IRA $400(\mathrm{OH})$, ( $3 \mathrm{ft}$. by 2 in.) which was well washed with glass-distilled water before use. The micronutrient elements which were added to the media after the purification were spectrographically pure reagents obtained from Johnson and Matthey, Hatton Garden, London, E.C. 1. Biotin was obtained in ampoules containing $25 \mu \mathrm{g}$. biotin from the Ashe Laboratories (Leatherhead, Surrey). The medium was dispensed in 200 ml. amounts in 11 . Erlenmeyer flasks, inoculated with a suspension of the fungus mycelium contained in sterile glass-distilled water, and incubated in the dark at $28^{\circ}$. The cultures were shaken daily to prevent sporulation of the fungus.

Preparation of cell-free extracts. The mycelial mats from normal and Modeficient cultures, collected separately in Buchner funnels, and washed well in glass-distilled water, were frozen for $3 \mathrm{hr}$. at $-17^{\circ}$. They were then ground in a mortar with three times their weight of cold $0 \cdot 1 \mathrm{M}$-phosphate buffer $(\mathrm{pH} \mathrm{7 \cdot 5)}$ and then in a Ten Broeck glass macerater (made to specification by Jencons Ltd., Hemel Hempstead, Hertfordshire) at $0^{\circ}$. The solutions were centrifuged at $2000 \mathrm{~g}$ for $10 \mathrm{~min}$. at $4^{\circ}$. Over $90 \%$ of each of the two enzymes was present in the supernatant solutions.

Enzyme assays. Catalase was determined in samples of the extracts by the perborate method (Feinstein, 1949); the enzyme activity being expressed as $\mu$ mole perborate degraded $/ 5 \mathrm{~min} . / \mathrm{mg}$. protein.

Peroxidase was assayed by the method of Smith, Robinson \& Stotz (1949) as the change in $\log I_{0} / I$ of $0.001 / \mathrm{min}$., calculated from 15 to $75 \mathrm{sec} . / \mathrm{mg}$. protein. Protein was determined by the method of Lowry, Rosebrough, Farr \& Randall (1951).

Radioassay of molybdenum-99 in enzyme fractions. Carrier-free ${ }^{99} \mathrm{Mo}$, as sodium molybdate, was obtained from A.E.R.E. Harwell. Ordinary sodium molybdate (A.R.) was added to the tracer so that $20 \mu \mathrm{g}$. Mo was labelled with $4 \mu \mathrm{C}{ }^{99} \mathrm{Mo} /$ l. culture solution. The culture solutions were first freed from Mo by the method of Nicholas (1952) and then inoculated with a suspension of the fungus mycelium. After 3 days of growth, $0.8 \mu \mathrm{C}{ }^{99} \mathrm{Mo} / 4 \mu \mathrm{g}$ Mo as sodium molybdate contained in $5 \mathrm{ml}$. glass-distilled water, was added aseptically to each flask containing $200 \mathrm{ml}$. culture medium. After a further 2 days of incubation the felts were harvested and the enzymes extracted as described above. The two enzymes were fractionated by ammonium sulphate precipita- 
tion, carbon adsorption at $4^{\circ}$ and by ethanol precipitation at $-15^{\circ}$. The protein fractions, dispensed in $0 \cdot 1 \mathrm{M}$-phosphate buffer ( $\mathrm{pH} \mathrm{7.5}$ ) were radio-assayed in an M6 type tube (Veal 16). Isotopic decay and minor scale fluctuations were allowed for by counting a sample of the standard solution used for the treatments after assay of every three or four experimental solutions.

\section{RESULTS \\ Effect of molybdenum deficiency}

The data in Fig. 1 show the effects of molybdenum deficiency on the content of the two iron-containing enzymes in the mycelial felts harvested after 3, 4 and 5 days of growth. The deficiencies of molybdenum in Expts. A, B and C resulted in yields of 35,50 and $65 \%$ of the weight of the normal non-deficient felts on the 5th day on growth.
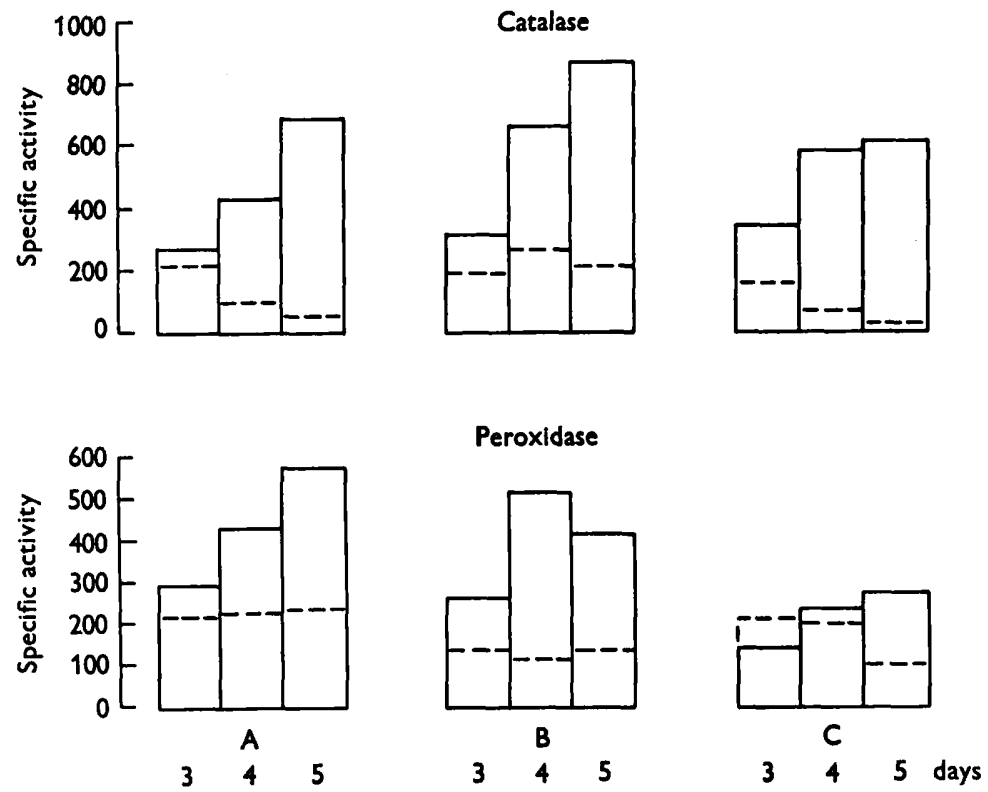

Fig. 1. The effect of the degree of Mo-deficiency on the content of catalase and peroxidase in Neurospora crassa after 3, 4 and 5 days of growth. In A, B and C, each subunit comprises mean values for catalase or peroxidase obtained in three independent experiments. Yields of approximately 35,50 and $65 \%$ of that of normal felts were obtained on the 5th day in $\mathrm{A}, \mathrm{B}$ and $\mathrm{C}$ respectively. $\longrightarrow$, catalase or peroxidase from normal felts;..- -, catalase or peroxidase from Mo-deficient felts.

Catalase production increased in the normal felts from the 3rd to the 5th day and the amount of peroxidase was usually greater on the 4th and 5th days than on the 3rd day. The effect of molybdenum in decreasing catalase and peroxidase activity was more pronounced at the 4th and 5th days. In Expt. C, where the deficiency was less severe, catalase production was markedly decreased at the three stages of growth, whereas peroxidase was decreased on the 5th day only. Thus a deficiency of molybdenum seems to decrease production of catalase before that of peroxidase. 
The fungus was grown with various quantities of Mo and the amounts of the two enzymes were determined in extracts of the felts; the results are illustrated in Fig. 2. An increase in the molybdenum content of the medium from 0 to $4 \mu \mathrm{g} . / 200 \mathrm{ml}$. basal solution was paralleled by increased production of the two enzymes in the felts. The maximum activities were reached with $4 \mu \mathrm{g}$. Mo/200 ml. basal solution; the addition of 8,16 and $32 \mu \mathrm{g}$. depressed the yields of the two enzymes.
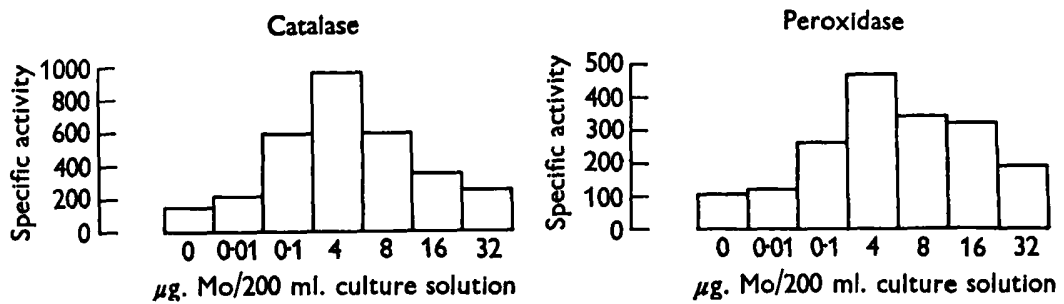

Fig. 2. Effect of different amounts of Mo in the culture solution on the yields of two ironcontaining enzymes. Enzyme units as in Table 1.
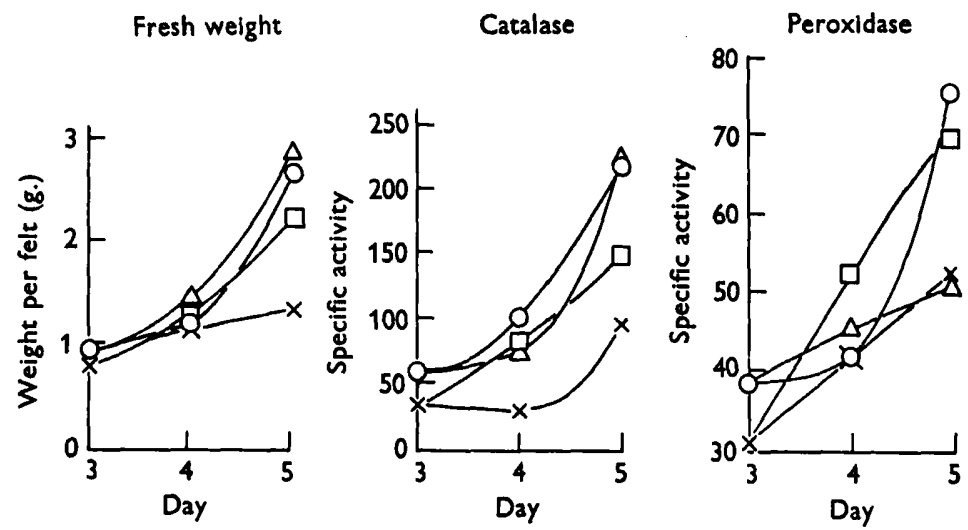

Fig. 3. Effect of concentration of Mo on fresh weight, and catalase and peroxidase contents of Neurospora crassa $\bigcirc-O$, normal felts; $\triangle-\Delta$, normal felts to which $4 \mu \mathrm{g}$. Mo/200 ml. culture solution was added aseptically after 3 days of growth. $\times-x$, Modeficient; $\square-\square$, Mo-deficient felts to which $4 \mu \mathrm{g}$. Mo/200 ml. culture solution was added as above. Enzyme units as in Table 1.

The effects on the weight and the production of the two iron-containing enzymes in the felts of adding Mo aseptically in vivo to normal cultures and to those deficient in Mo, after 3 days of growth, are illustrated in Fig. 3. The addition of Mo to the deficient felts resulted in a restoration of the weight to about $75 \%$ of that of the normal felts after a further 2 days of growth. The amount of catalase recovered to 85 and $75 \%$ of that in normal felts at the 4th and 5th day respectively. After addition of Mo to the deficient felts, the peroxidase activity at the 4th day exceeded the values in the control felts. On the 5th day, the peroxidase content was about $95 \%$ of that in the normal felts. 
It was not possible to reconstitute the two enzymes to the normal levels by adding $\mathbf{0 . 1}$ or $1 \mu \mathrm{g}$. $\mathrm{Mo}^{6+}$ (as sodium molybdate) or $\mathrm{Mo}^{5+}$ (as molybdenum pentachloride) to homogenates of felts deficient in Mo. Mixing extracts of normal mycelial felts with those from Mo-deficient felts proved that there was neither an inhibitor in the deficient felts nor an activator in the normal ones.

\section{Effect of hydrogen peroxide}

In order to establish whether Mo-deficiency was affecting the formation of the common substrate of the two iron-containing enzymes, hydrogen peroxide in graded amounts was added aseptically to the cultures of normal and deficient felts after 2 days of growth. Treated and non-treated felts were harvested immediately and others after a further 1, 2 and 3 days growth (viz. at the $3 \mathrm{rd}, 4$ th and 5 th days of incubation). The results for the addition of $6 \mathrm{mg} . \mathrm{H}_{2} \mathrm{O}_{2} / 200 \mathrm{ml}$. culture medium is illustrated in Fig. 4. The addition of the $\mathrm{H}_{2} \mathrm{O}_{2}$ had no effect on the weight of felt of the control or the Mo-deficient cultures. On the 5 th day catalase activity was partially restored (18\% of normal) and peroxidase activity showed a $50 \%$ increase. There was no comparable effect in the control felts. The Mo content of the hydrogen peroxide added, determined by the bioassay method (Nicholas, 1952) was negligible. Thus no Mo was introduced in the hydrogen peroxide, as confirmed by finding no increase in the yield of Mo-deficient felts treated with this peroxide solution.
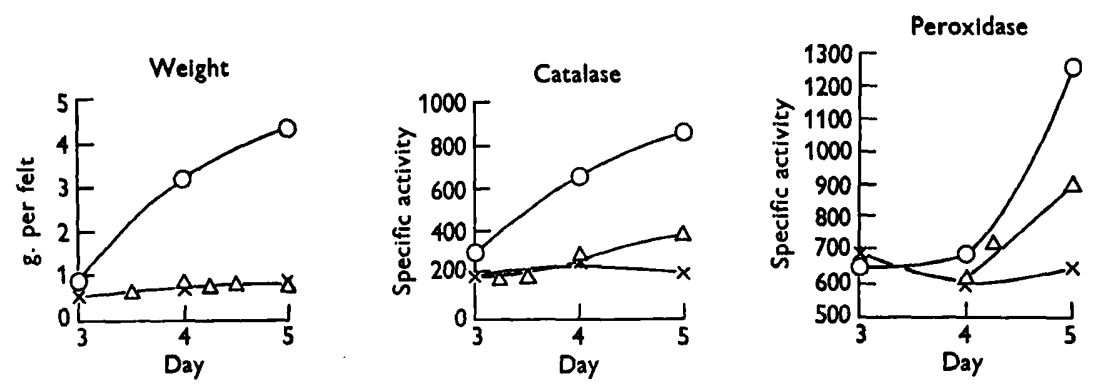

Fig. 4. Effect of hydrogen peroxide on fresh weight, catalase and peroxidase in Neurospora crassa grown with and without Mo. $O-0$, normal felts; $x-x$, Mo-deficient felts; $\triangle-\triangle$, Mo-deficient felts to which $6 \mathrm{mg} . \mathrm{H}_{2} \mathrm{O}_{2}$ was added in vivo to $200 \mathrm{ml}$. culture medium. Enzyme units as in Table 1.

\section{Purification of catalase and peroxidase in relation to their molybdenum contents}

To establish whether or not the effect of Mo-deficiency was on hydrogen peroxide production only, the two enzymes were purified and the Mo content and enzyme activity of the various fractions determined. To facilitate Mo determinations, $4 \mu \mathrm{c}$. ${ }^{99} \mathrm{Mo} / 20 \mu \mathrm{g}$. Mo were incorporated/l. culture medium. Mycelial felts grown in $4 \mathrm{l}$. labelled media were used for each fractionation. The ${ }^{99}$ Mo content of the various fractions were determined by radio-assay.

The results for catalase and peroxidase are given in Tables 1 and 2. The correlations between the value of ${ }^{99} \mathrm{Mo} / \mathrm{mg}$. protein and the specific activity of 


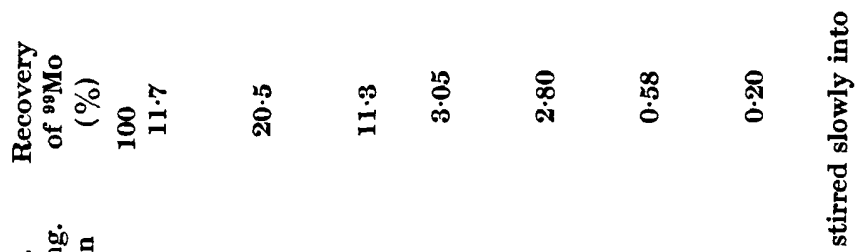

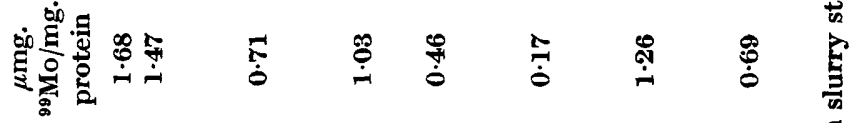

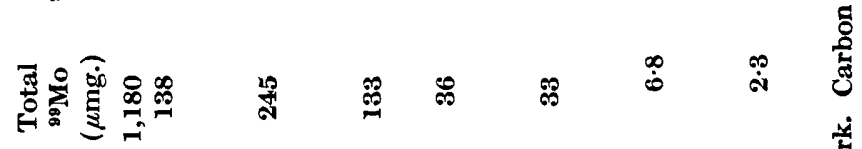

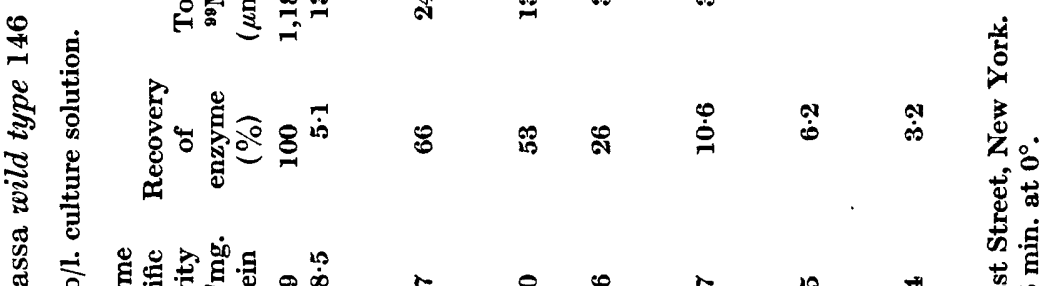

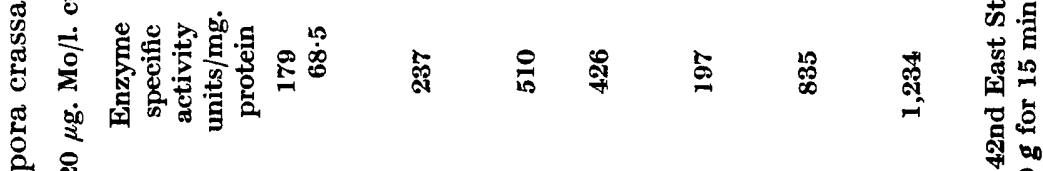

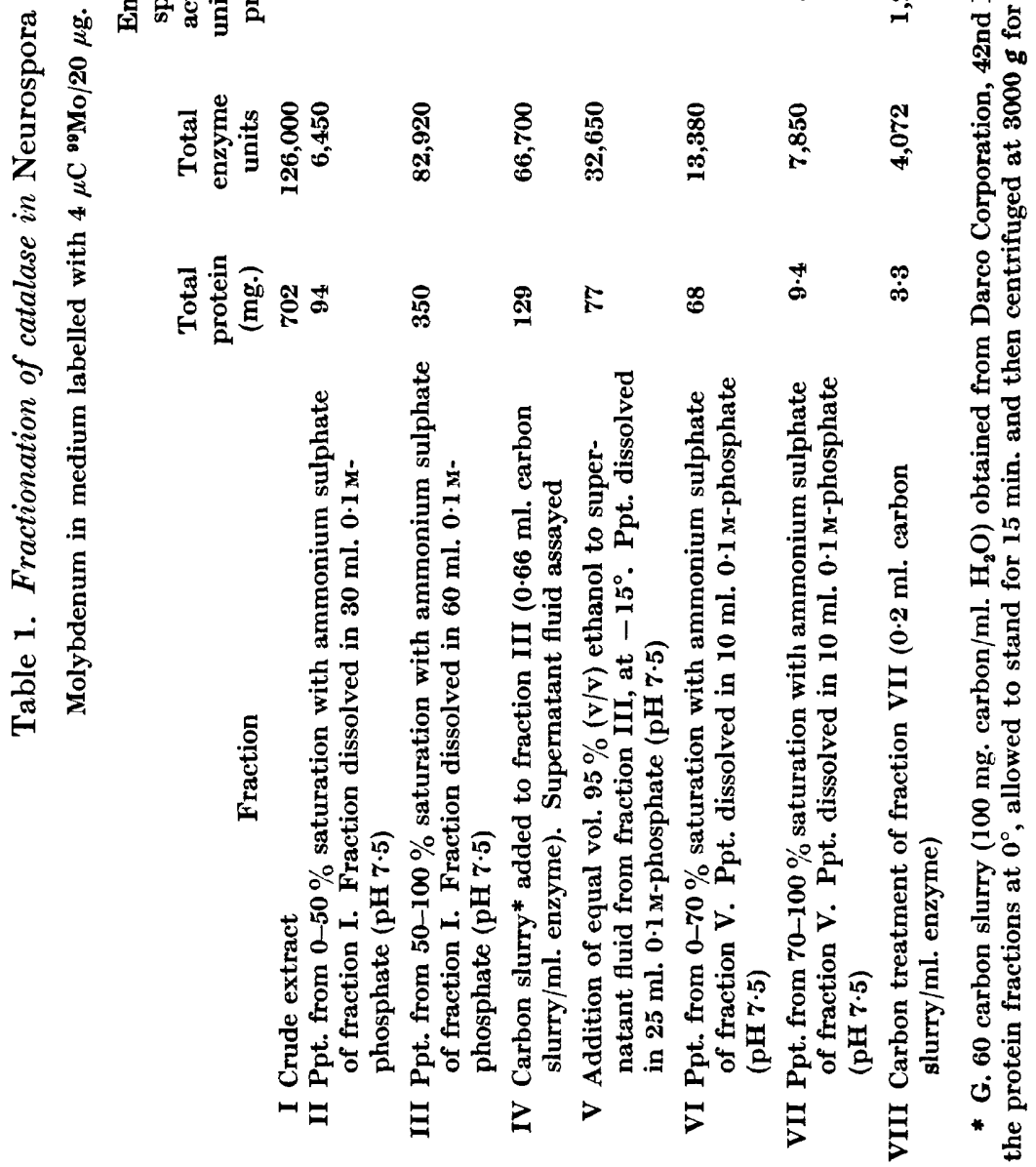




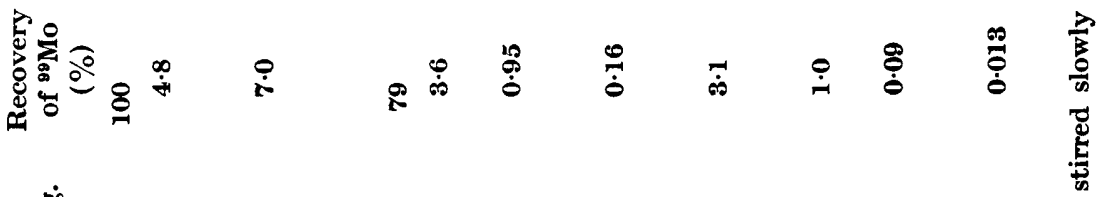

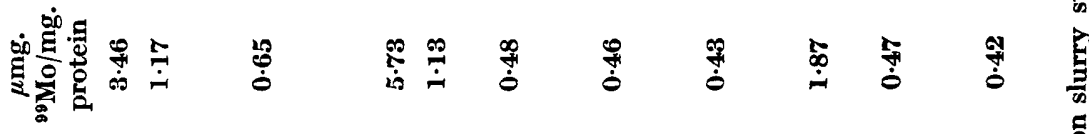

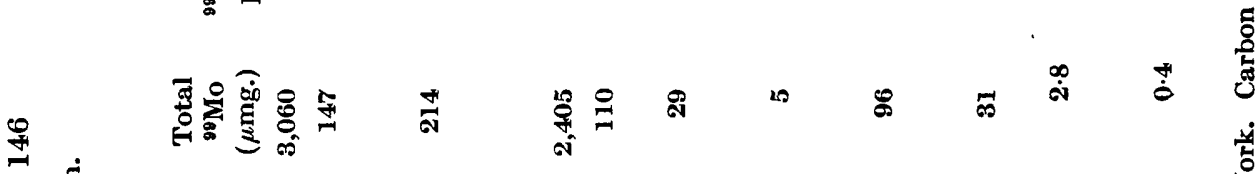

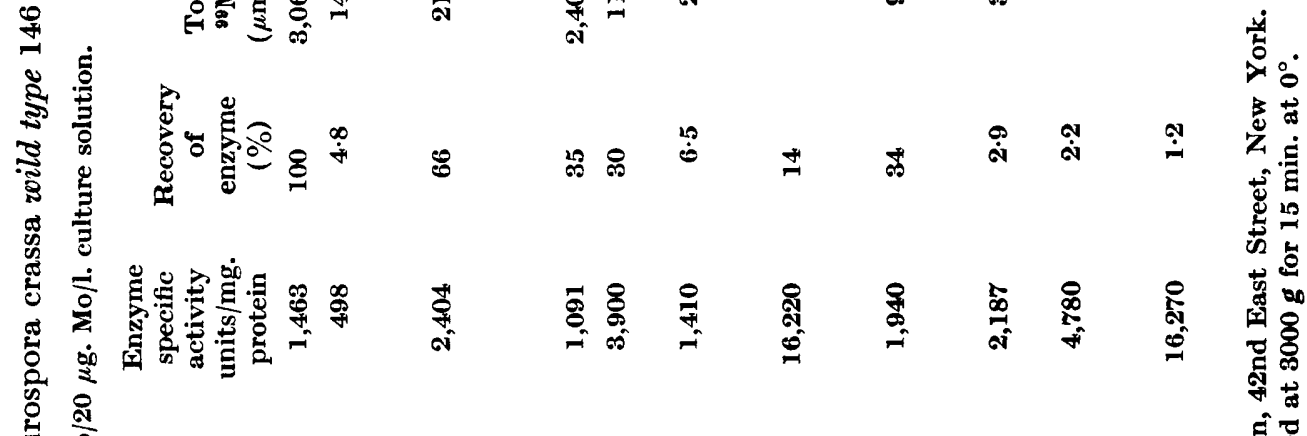
竞竞

ฐ

案

है:

赔

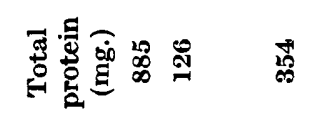

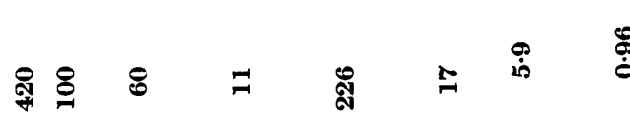

88

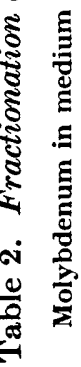

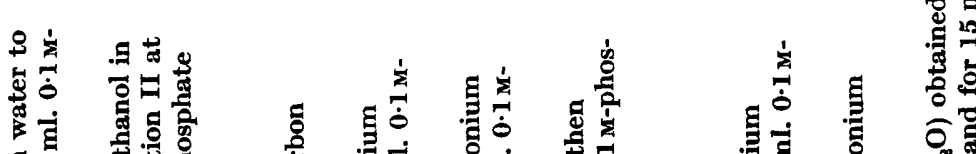

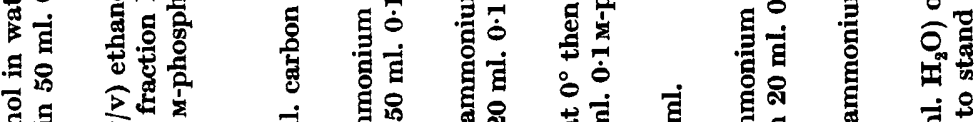

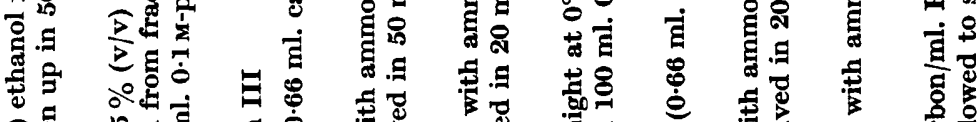

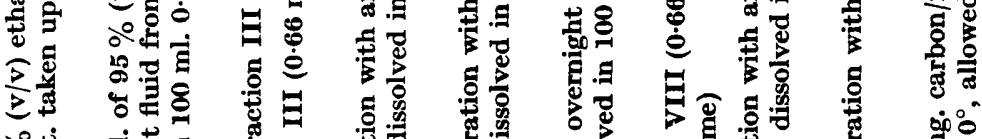

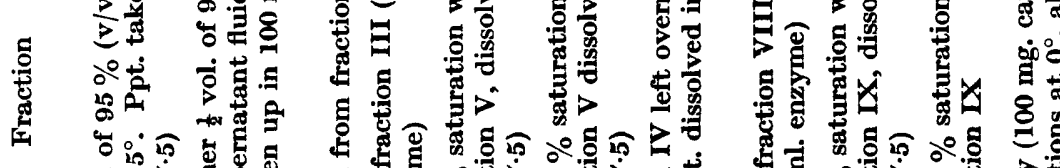

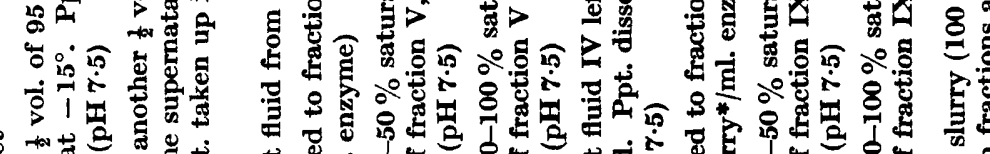

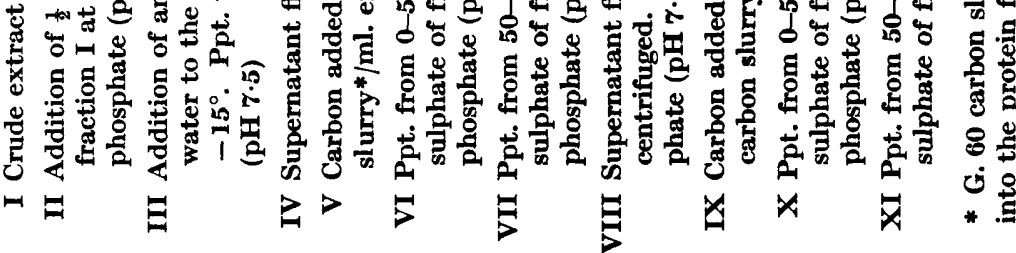


catalase or peroxidase (enzyme units/mg. protein) are illustrated in Figs. 5 and 6. It is clear that there was no positive correlation between the Mo content of either enzyme and its activity, so that molybdenum does not appear to concentrate in these enzymes as they are purified. Further, the addition of $\mathbf{M o}^{6+}$ as sodium molybdate or $\mathrm{Mo}^{5+}$ as molybdenum pentachloride did not stimulate the activity of the purified fractions of either enzyme. Thus molybdenum seems unlikely to be a constituent of these two iron-containing enzymes.

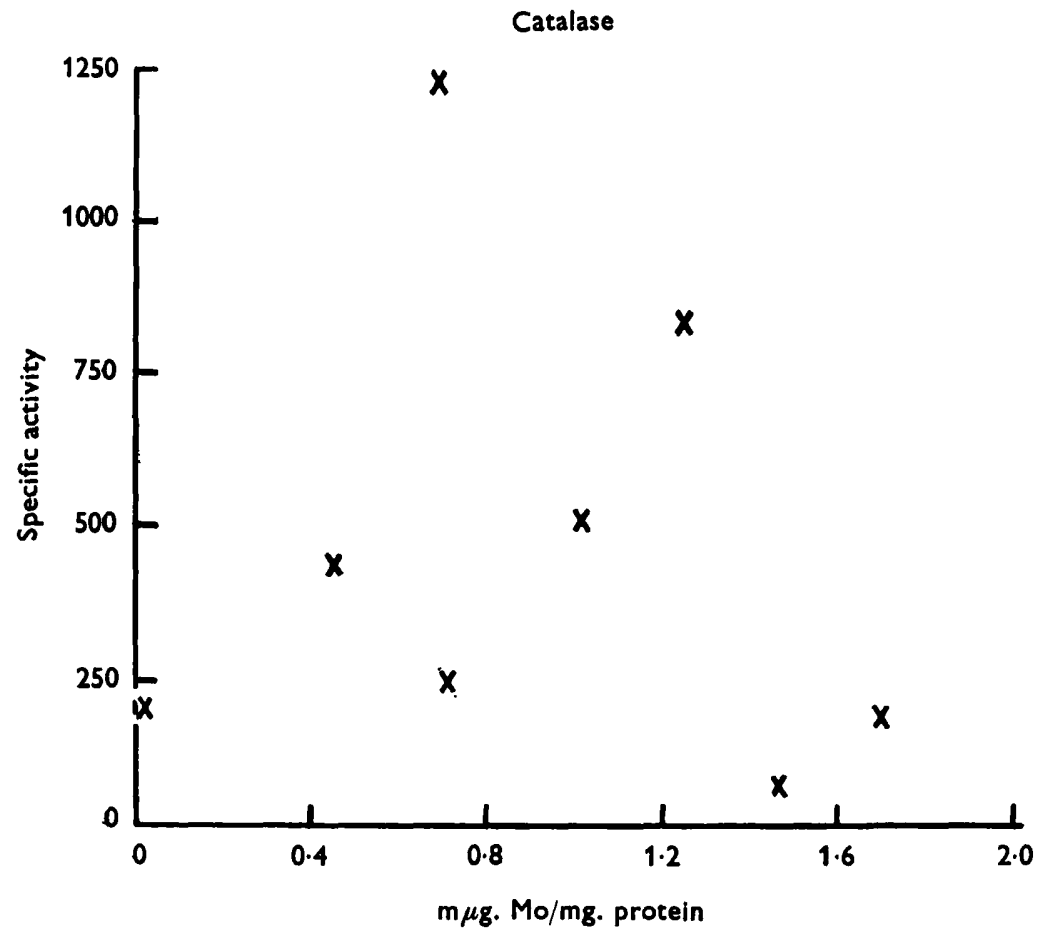

Fig. 5. Relation between specific activity of catalase (units $/ \mathrm{mg}$. protein) and $\mathrm{m} \mu \mathrm{g}$. ${ }^{90} \mathrm{Mo} / \mathrm{mg}$. protein in the various protein fractions of the fungus.

\section{DISCUSSION}

Although a deficiency of molybdenum depressed catalase and peroxidase activities in Neurospora crassa, possibly by decreasing the amount of their common substrate hydrogen peroxide, the mechanism whereby this occurs is not clear. It is known that riboflavin and flavin mononucleotide (FMN) or flavin adenine dinucleotide (FAD) react with oxygen to form hydrogen peroxide (Theorell, 1951). It has also been shown that some flavoprotein enzymes may be decreased in activity when molybdenum is deficient. Thus nitrate reductase in fungi, bacteria and green plants, which has FAD as the native flavin coenzyme, has been shown to contain molybdenum which undergoes a valence change involving $\mathrm{Mo}^{6+}$ and $\mathrm{Mo}^{5+}$ during the enzymic reduction of nitrate (Nicholas \& Stevens, 1955). In Pseudomonas fluorescens grown at low oxygen pressure, the electron transfer system is mainly iron-dependent, 


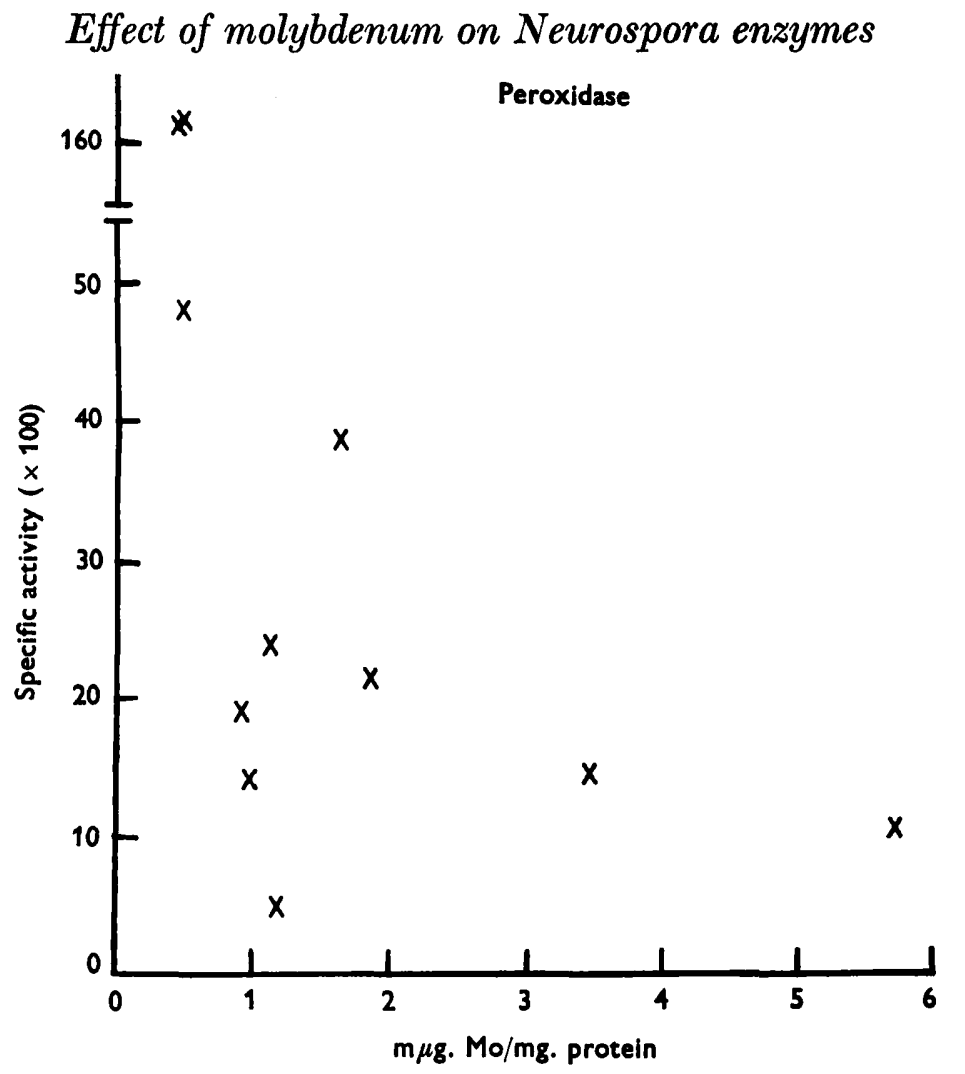

Fig. 6. Relation beteeen specific activity of peroxidase (units/mg. protein $\times 100$ and $\mathrm{m} \mu \mathrm{g} .{ }^{90} \mathrm{Mo} / \mathrm{mg}$. protein, in the various protein fractions of the fungus.

whereas under high oxygen pressures a molybdo-flavoprotein system became dominant (Lenhoff, Nicholas \& Kaplan, 1956). Thus a deficiency in hydrogen peroxide in Neurospora crassa may well arise from a depletion in molybdenumdependent flavoproteins which have the capacity to react with oxygen to form peroxides, this in turn diminishing the degree of induced formation of catalase and peroxidase.

Thanks are due to Mr C. P. Lloyd-Jones, B.Sc., for providing a counting service for the radioassay of ${ }^{99} \mathrm{Mo}$ and to $\mathrm{Mr}$ G. Mabey for technical assistance. Mr G. H. Jones kindly made the photographic records.

\section{REFERENCES}

Feinstein, R. N. (1949). Perborate as substrate in a new assay of catalase. J. biol. Chem. 180, 1197.

Lenhoff, H. M., Nicholas, D. J. D. \& Kaplan, N. O. (1956). Effects of oxygen, iron, and molybdenum on routes of electron transfer in Pseudomonas fluorescens. J. biol. Chem. 220, 983.

Lowry, O. H., Rosebrough, N. L., Farr, A. L. \& Randall, R. J. (1951). Protein measurement with the Folin phenol reagent. J. biol. Chem. 193, 265.

Nicholas, D. J. D. \& Fielding, A. H. (1951). Use of Aspergillus niger (M) for the determination of magnesium, zinc, copper and molybdenum available in soils to crop plants. J. hort. Sci. 26, 125. 
Nicholas, D. J. D. (1952). The use of fungi for determining trace metals in biological materials. Analyst, 77, 629.

Nicholas, D. J. D., Nason, A. \& McElroy, W. D. (1954). Molybdenum and nitrate reductase. I. Effect of molybdenum on the Neurospora enzyme. J. biol. Chem. 207, 341.

Nicholas, D. J. D. \& Nason, A. (1954a). Molybdenum and nitrate reductase. II. Molybdenum as a constituent of nitrate reductase. J. biol. Chem. 207, 353.

Nicholas, D. J. D. \& Nason, A. (1954b). Mechanism of action of nitrate reductase from Neurospora. J. biol. Chem. 211, 183.

Nicholas, D. J. D. \& Nason, A. (1954c). Diphosphopyridine-nucleotide-nitrate reductase from Escherichia coli. J. Bact. 69, 580.

Nrcholas, D. J. D. \& Nason, A. (1955). Role of molybdenum as a constituent of nitrate reductase from soybean leaves. Plant Physiol. 30, 135.

Nicholas, D. J. D. \& Stevens, H. M. (1955). Valency changes of molybdenum during the enzymatic reduction of nitrate in Neurospora. Nature, Lond. 176, 1066.

Nicholas, D. J. D. (1956). Effect of molybdenum deficiency on catalase and peroxidase in Neurospora. Nature, Lond. 178, 148.

Smith, F. G., Robinson, W. B. \& Stotz, E. (1949). A colorimetric method for the determination of peroxidase in plant material. J. biol. Chem. 179, 881.

Theoreld, H. (1951). In The Enzymes. Ed. Sumner, J. B. \& Myrbäck, K. 2, i, p. 335. New York: Academic Press.

(Received 17 June 1957) 